\title{
THE EFFECT OF BRANDING, PRODUCT QUALITY, AND REFERENCE GROUP ON PURCHASING DECISIONS THROUGH PROMOTION AS INTERVENTION VARIABLES (CASE STUDY OF SAMSUNG CUSTOMER AT METEOR CELL STORE MALANG)
}

\author{
Sudirman \\ Mahasiswa Magister Manajemen Pascasarjana Universitas Islam Malang \\ Email : Sudirmanhamzah4@gmail.com
}

\begin{abstract}
Branding, product quality, reference group, and promotion is one that influences purchasing decisions. Buyers who have a high brand image will lead to purchasing decisions. This research was conducted at the Meteor Cell Store Malang. The purpose of this study was to examine and analyze the effect of branding on promotion, product quality on promotion, reference group on promotion, branding on purchasing decisions, product quality on purchasing decisions, reference groups on purchasing and promotion decisions on purchasing decisions.

The variables used in this study are branding, product quality, and reference group as endogenous variables. Exogenous variables are purchasing decisions and the intervening variable is a purchasing decision. The samples used in this study were Meteor Cell Store Malang's customers who bought Samsung Brand Smartphones, as many as 95 respondents. The data collection method used is a questionnaire. The analysis used includes the instrument test, classic assumption test, normality test and hypothesis test using path analysis with the help of SPSS 21.0 For Windows.

The results of this study indicate that branding and product quality have a significant and positive direct effect on promotion, while the benchmark group variable does not directly influence promotion. The brand image variable and product quality have a significant and positive effect on purchasing decisions, while the reference group variable has no effect on purchasing decisions. This shows that the reference group is no longer needed by consumers of the Meteor Cell Store Malang, they prefer to find information about Samsung smartphones via the internet and other information when viewed from the respondents' educational background for they are on average are graduate students.
\end{abstract}

Keywords: Branding, Product Quality, Reference Group, and Purchasing Decision.

\section{PENDAHULUAN}

Teknologi dan informasi pada saat ini sudah berkembang dengan pesat. hal ini menjadi kebutuhan manusia juga ikut berkembang dan semakin kompleks. Perusahaan berlomba-lomba untuk menciptakan produk dan jasa demi memenuhi kebutuhan dan juga keinginan pasar (konsumen) yang beragam.

Banyaknya merek smartphone berbasis OS Android yang masuk ke Indonesia, namun PT Samsung Electronics Indonesia (SEI) yang mampu menjadi pemimpin smartphone berbasis OS Android dengan produk andalanya Galaxy Series. Berdarkan riset lembaga Growth for Knowledge (GFK) seperti yang dikemukakan oleh Budi Janto, direktur bisnis PT Samsung Electronics Indonesia Samsung menjadi merek nomor satu untuk kategori smartphone Android dengan pangsa pasar tercatat $80 \%$ dan 
Computer $40 \%$ dibandingkan dengan merek lain untuk kategori Smartphone Android.

Store Meteor Cell di Malang berdiri sejak tahun 2009, pertama Store ini berlokasi di JIn. Soekarno Hatta Malang, hampir 10 Tahun Store Meteor Cell sudah menjadi salah satu Store Smartphone paling besar di Malang dengan penjualan setiap hari kurang lebih 40 unit, dengan kemajuan tersebut, maka dilakukan perluasan Store pindah ke Jln Gayayana No 158 menjadi beberapa bagian, sehingga menampung keseluruhan penjualan Smartphone dari semua vendor dan juga pembelian Accessories, hingga kini Meteor Cell sudah memiliki 4 cabang di Malang.

Merek yang diingat mempunyai kesan tersendiri dihati para konsumen. kesan tersebut dapat menimbulkan citra pada merek itu sendiri. citra merek merupakan representasi dan keseluruhan persepsi terhadap merek dan dibentuk dari informasi dan pengalaman masa lalu terhadap merek tersebut. citra terhadap merek berhubungan dengan sikap yang berupa keyakinan dan preferensi terhadap suatu merek, akan lebih meyakinkan untuk melakukan pembelian.

Kualitas mempunyai pengertian yang sangat penting dalam keputusan pembelian. apabila kualitas produk sangat baik maka kemungkinan besar konsumen akan melakukan pembelian ulang pada produk tersebut. untuk meiliki kualitas produk yang ditargetkan maka dibutuhkan suatu standarisasi kualitas. cara ini bermaksud untuk menjaga kualitas produk yang diproduksi dapat memenuhi standar yang telah ditetapkan sebelumnya, sehingga perusahaan tidak kehilangan kepercayaan dari para konsumennya. definisi dari kualitas produk adalah kemampuan sebuah produk dalam memperagakan fungsihnya, hal ini termasuk keseluruhan durabilitas, reliabilitas, ketepatan, kemudahan pengoperasian, dan reparasi produk, juga atribut produk lainnya". (Kotler dan Amstrong, 2012:283). suatu produk dinyatakan berkualitas jika produk tersebut memenuhi kebutuhan dan keinginan dari konsumen. kualitas produk ditentukan oleh konsumen dan pengalaman konsumen terhadap produk tersebut.

Konsumen dalam melakukan keputusan pembelian tidak hanya dipengaruhi oleh dirinya sendiri, akan tetapi juga dipengaruhi oleh kelompok rujukan ataupun kelompok acuan. Schiffman dan Kanuk (2008:271) dalam konteks perilaku konsumen, konsep kelompok acuan merupakan gagasan yang sangat penting dan berpenagruh besar terhadap keputusan pembelian atau konsumsi mereka.

Promosi sangat diperlukan oleh perusahaan karena disatu pihak meyakinkan konsumen terhadap produk yang ditawarkan sedangkan pihak lain sangat menentukan suksesnya perusahaan menghadapi persaingan pasar. promosi yang dilakukan perusahaan banyak sekali bentuknya, maka dari itu terdapat konsep tentang bauran promosi (promotion mix).

Keputusan pembelian konsumen sangat erat kaitanya dengan pengetahuan konsumen terhadap suatu produk. sehingga perusahaan harus mampu memperkenalkan produk secara massif untuk menambah pengetahuan konsumen. selain itu, gaya hidup konsumen dan kelompok acuan dari konsumen juga turut andil dalam memantapkan suatu tahap 
keputusan pembelian setelah data kuesioner sudah di bagikan peneliti akan melakukan analisis sesuai dengan metode analisis yang digunakan dalam penelitian ini yaitu dengan Path Analilysis.

Berdasarkan uraian latar belakang masalah diatas maka penulis bermaksud untuk melakukan penelitian dengan judul "Pengaruh Citra Merek, Kualitas Produk dan Kelompok Acuan Terhadap Keputusan Pembelian Melalui Promosi Sebagai Variabel Intervening (Studi Kasus Pada Konsumen Pembeli Smartphone Samsung di Store Malang - Jawa Timur).

\section{KAJIAN TEORI Citra Merek}

Menurtut Tjiptono (2008:104), "Merek merupakan nama, istilah, tanda, symbol atau lambang, desain, warna, gerak, atau kombinasi atributatribut produk lainnya yang diharapkan dapat memberikan identitas dan direfensiasi terhadap produk pesaing".

Menurut Kotler (2013:69), "Citra merek muncul bersama produk atau jasa yang sulit dibedakan, atau mnilai mutunya, atau menyampaikan pernyataan tentang pengguna. strateginya meliputi upaya menciptakan desain tersendiri, mengasosiasikannya dengan pengguna selebritis, atau menciptakan citra iklan yang kuat".

\section{Kualitas Produk}

Kualitas produk merupakan penggerak kepuasan pelanggan yang pertama dan kualitas produk ini adalah dimensi yang global. kualitas produk merupakan suatu hal yang penting dalam menentukan pemilihan suatu produk oleh konsumen. produk yang ditawarkan haruslah suatu produk yang bener-bener teruji dengan baik mengenai kualitasnya.

Kualitas produk Menurut Kotler dan Armstrog (2008:67) adalah "Sekumpulan ciri-ciri karakteristik dari barang dan jasa yang mempunyai kemampuan untuk memenuhi kebutuhan yang merupakan suatu pengertian dari gabungan daya tahan, keandalan, ketepatan, kemudahan pemeliharaan serta atribut-atribut lainnya dari suatu produk".

Dimensi kualitas produk Menurut Tjiptono (2008:109) adalah :

(1).Performance (Kinerja).(2).Durability (Daya tahan), (3). Corformance to Specifications (Kesesuaian dengan spesikasi), (4) Features (Fitur), (5) Reliability (Reliabilitas), (6) Aesthetics (Estetika), (7).Perceived quality (Kesan kualitas), (8). Serviceability.

\section{Kelompok Acuan}

Kelompok acuan/rujukan (reference group) adalah kelompok yang digunakana sebagai alat ukur (standar) untuk menilai diri sendiri atau untuk membentuk sikap, group reference melibatkan satu atau lebih orang yang dijadikan sebagai dasar pembanding atau titik reference dalam membentuk tanggapan afeksi dan kognisi serta menyatakan perilaku seseorang. Group reference ukuranya beragam (dari satu hingga ratusan orang), dapat memiliki bentu nyata (orang sebenarnya), atau tak nyata dan simbolik (eksekutif yang berhasil atau bintang olahraga). group reference seseorang dapat berasal dari kelas sosial, sub-budaya, atau bahkan budaya yang sama atau berbeda. 
Dharmmesta dan Handoko (2008), menjelaskan bahwa "kelompok acuan (Reference Group) adalah sekelompok sosial yang menjadi ukuran seseorang untuk membentuk kepribadian dan perilakunya". Berikut adalah macam-macam kelompok Acuan (Reference Group) yang mempengaruhi konsumen menurut Sumarwan (2003:250) antara lain : a.Keluarga b. Kelompok c. Persahabatan d.Kelompok Belanja e. Kelompok Kerja Promosi

Menurut Tjiptono (2008:229), "Promosi Penjualan adalah bentuk persuasi langsung melalui penggunaan berbasis intensif yang dapat diatur untuk merangsang pembelian produk dengan segera dan meningkatkan jumlah barang yang dibeli pelanggan".

Promosi merupakan alat komunikasi dan penyampaian pesan bersifat memberitahukan, membujuk, mengingatkan kembali kepada konsumen, para perantara atau kombinasi keduanya. dalam promosi terdapat beberapa unsur yang mendukung jalanya sebuah promosi tersebut yang biasa disebut bauran promosi.

\section{Keputusan Pembelian}

Keputusan Pembelian Menurut Tjiptono (2008:23), "Proses Pembelian bermula jauh sebelum seseorang membeli suatu produk dan berlangganan lama sesudahnya. Ini mendorong produsen atau pemasar untuk berfokus pada seluruh proses pembelian dari pada sekedar pada proses pembelian". Dalam penelitian ini dapat diturunkan menjadi item-item berdasarkan indicator keputusan pembelian (Kotler, 2002:204). a.Keinginan konsumen b. Harga terjangkau c. Kualitas produk d. Rekomendasi dari keluarga atau teman.

\section{METODE PENELITIAN}

Berdasarkan rumusan masalah dan tujuan penelitian yang ingin dicapai dalam penelitian ini, maka penelitian ini tergolong dalam jenis explanatory research (penelitian eksplanatori), yakni penelitian yang digunakan sebagai pengujian hipotesis atau teori yang berguna memperkuat hipotesis atau teori ataupun menolak hipotesis yang telah diteliti sebelumnya. penelitian deskriptif akan berubah menjadi penelitian hipotesis (hypothesis testing) atau explanatory research (penelitian penjelasan). Apabila penelitian yang dilakukan untuk mengetahui seberapa besar pengaruh antara variabel-variabel dengan cara menguji hipotesis.

Penelitian ini dilakukan pada Store Meteor Cell ada 4 cabang diantaranya (Meteor Cell Dinoyo, Meteor Cell Blimbing, Meteor Cell Singosari dan Meteor Cell Talun) Malang - Jawa Timur. Penelitian ini dimulai sejak Bulan Oktober 2018 sampai dengan Bulan Mei 2019.

"Populasi adalah seluruh kumpulan jumlah yang terdiri dari banyak elemen-elemen yang menunjukkan ciri-ciri tertentu yang dapat digunakan untuk membuat kumpulan", (Sanusi, 2014). Populasi yang digunakan dalam penelitian ini adalah para konsumen yang membeli Smartphone Samsung di Store Meteor Cell Malang selama tahun 2019 sebanyak 1.800 populasi. Sampel dalam penelitian ini adalah 95 responden dari 1.800 populasi yang ada. Sampel yang tidak akurat dan tidak tepat akan 
memberikan kesimpulan riset yang tidak diharapkan atau dapat dihasilkan kesimpulannya salah yang menyesatkan Menurut Sugiyono (2012:91).

Definisi operasional variabel merupakan petunjuk tentang bagaimana variabel diukur, sehingga peneliti dapat mengetahui baik atau buruk pengukuran tersebut. variabel - variabel yang digunakan dalam penelitian ini ada 5 variabel di antaranya yaitu ada 3 variabel eksogen, dan 1 variabel endogen dan 1 variabel Intervening. dimana variable kualitas produk, citra merek dan kelompok acuan merupakan variable eksogen, dan keputusan pembelian sebagai variable endogen serta promosi sebagai variable intervening.

\section{Variabel Endogen}

\section{Citra Merek}

Citra merek muncul bersama produk atau jasa yang sulit dibedakan, atau menilai mutunya, atau menyampaikan pernyataan tentang pengguna, strateginya meliputi upaya menciptakan desain tersendiri, mengasosiasikanya dengan pengguna selebriti atau menciptakan citra iklan yang kuat.

Untuk indicator citra merek menggunakan teori Sutisna (2001:80) adapun indicator di antaranya :

\section{(a).Citra Perusahaan, (b). Citra Pemakai, (c). Citra Produk}

\section{Kualitas Produk}

Kualitas produk merupakan penggerak kepuasan pelanggan yang pertama dan kualitas produk ini adalah dimensi yang global. kualitas produk merupakan suatu hal yang penting dalam menentukan pemilihan suatu produk oleh konsumen. produk yang ditawarkan haruslah suatu produk yang bener-bener teruji dengan baik mengenai kualitasnya.

Adapun indicator - indikator kualitas produk Menurut teori Kotler dan Armstrong (2012:283) antara lain :

(a). Performance (Kinerja) (b).Durability (daya tahan) (c).Conformance specifications (Kesesuaian dengan spesifikasi) (d). Features (Fitur) (e).Reliability (Reabilitas) (f).Aesthetics (Etestika) (g). Perceived Quality (Kesan Kualitas) (h). Serviceability

\section{Kelompok Acuan}

Kelompok acuan/rujukan (reference group) adalah kelompok yang digunakana sebagai alat ukur (standar) untuk menilai diri sendiri atau untuk membentuk sikap. group reference melibatkan satu atau lebih orang yang dijadikan sebagai dasar pembanding atau titik reference dalam membentuk tanggapan afeksi dan kognisi serta menyatakan perilaku seseorang.

Adapun indicator kelompok acuan menurut Peter dan Olson (2014:133) di antaranya :
a. Informasional
b. Utilitarian
c. Ekspresi Nilai

\section{Variabel Endogen}

\section{Keputusan Pembelian}

Keputusan pembelian dapat diukur dengan indicator yang digunakan menurut Kotler dan Armstrong (2012:157) adapun indikatornya sebagai berikut : 
$\begin{array}{llll}\text { (a).Pengenalan masalah (b).Pencarian informasi } & \text { (c).Evaluasi }\end{array}$ alternative (d) Keputusan pembelian Evalusai pasca pembelian

\section{Variabel Intervening}

\section{Promosi}

Promosi Penjualan merupakan bentuk persuasi langsung melalui penggunaan berbasis intensif yang dapat diatur untuk merangsang pembelian produk dengan segera dan meningkatkan jumlah barang yang dibeli pelanggan".

Menurut Kotler yang tercantum dalam buku karangan Djaslim (2004:172) Indikator dari variable promosi antara lain :

a. Periklanan (Advertising)

b. Promosi Penjualan (Sales Prmotion)

c. Hubungan masyarakat dan publisitas (Public relation and publicity

d. Penjualan personal (personal selling) e.Pemasaran langsung.

Dalam penelitian ini jenis data yang digunakan adalah data primer dan data sekunder :

1. Data Primer 2. Data Sekunder

Teknik pengumpulan data yang digunakan dalam penelitian ini adalah kuesioner dan studi pustaka.

Metode analisis dalam penelitian ini adalah metode kuantitatif. Menurut Indriantoro dan Supomo (2002:120),penelitian kuantitatif adalah penelitian yang menekankan pada pengujian teori-teori melalui pengukuran variabel-variabel penelitian dengan angka-angka dan melakukan analisis data dengan prosedur statistic (SPSS Versi 21). Sedangkan metode analisis data dalam penelitian ini menggunakan Path Analisis (Analisis Jalur). Adapun tahap analisis tersebut adalah sebagai berikut :

Analisis Jalur merupakan perluasan dari analisis regresi linier berganda, atau analisis jalur adalah penggunaan analisis regresi untuk menaksir hubungan kausalitas antar variable (Model Causal) yang telah ditetapkan sebelumnya berdasarkan teori. analisis jalur sendiri tidak dapat menentukan hubungan sebab-akibat dan juga tidak digunakan sebagai substitusi bagi peneliti untuk melihat hubungan kausalitas antar variable. Hubungan kausalitas antar variable telah dibentuk dengan model berdasrkan landasan teori. apa yang dapat dilakukan oleh analisis jalur adalah menentukan pola hubungan antara tiga atau lebih variable dan tidak dapat digunakan untuk mengkonfirmasi atau menolak hipotesis kausalitas imajiner (Ghozali, 2016). sobel.

Pengujian hipotesis dalam penelitian ini menggunakan uji t dan uji
1. Uji t (t-test)
2. Uji Sobel. 


\section{HASIL ANALISIS DATA}

\section{Profil Lokasi Penelitian}

\section{Gambaran Umum Store Meteor Cell Malang}

Store Meteor Cell di Malang berdiri sejak tahun 2009, pertama Store ini berlokasi di Jln. Soekarno Hatta Malang, hampir 10 Tahun Store Meteor Cell sudah menjadi salah satu Store Smartphone paling besar di Malang dengan penjualan setiap hari kurang lebih 40 unit, dengan kemajuan tersebut, maka dilakukan perluasan Store pindah ke Jln. Gajayana No.158 menjadi beberapa bagian, sehingga menampung keseluruhan penjualan Smartphone dari semua vendor dan juga pembelian Accessories hingga kini Meteor Cell sudah memiliki 4 cabang di Malang di antaranya, (1). Meteor Cell - Dinoyo Jln.Gajayana No.158, (2). Meteor Cell - Talun Jln. KH.Hasyim Ashari No.7, (3). Meteor Cell - Blimbing Jln. Borobudur No.10 A-B, dan (4). Meteor Cell - Singosari Jln. Raya Singosari No.82.

\section{Uji Normalitas}

Tabel 4.1

Hasil Uji Normalitas Kolmogorov_Smirnov

\begin{tabular}{|c|c|c|c|}
\hline & $\begin{array}{l}\text { Unstandardized } \\
\text { Residual }\end{array}$ & $\begin{array}{l}\text { Unstandardized } \\
\text { Residual }\end{array}$ \\
\hline & & $\begin{array}{l}\text { Persamaan I } \\
(\mathrm{Z}) \\
\mathrm{X}_{1}, \mathrm{X}_{2}, \mathrm{X}_{3} \\
\text { terhadap } \mathrm{Z} \\
\end{array}$ & $\begin{array}{l}\text { Persamaan II (Y) } \\
\mathrm{X}_{1}, \mathrm{X}_{2}, \mathrm{X}_{3} \\
\text { dan } \mathrm{Z} \text { ke } \mathrm{Y}\end{array}$ \\
\hline $\mathrm{N}$ & & 95 & 95 \\
\hline \multirow{2}{*}{$\begin{array}{l}\text { Normal } \\
\text { Parameters }\end{array}$} & Mean & 0,000000 & 0,000000 \\
\hline & Std.Deviation & 1,36676068 & 0,58846179 \\
\hline \multirow{3}{*}{$\begin{array}{l}\text { Most Extreme } \\
\text { Differences }\end{array}$} & Absolute & 0.067 & 0.095 \\
\hline & Positive & 0.040 & 0.093 \\
\hline & Negative & -0.067 & -0.095 \\
\hline $\begin{array}{l}\text { Kolmogorov- } \\
\text { Smirnov Z }\end{array}$ & & 0.651 & 0.925 \\
\hline $\begin{array}{l}\text { Asymp.Sig. (2- } \\
\text { tailed) }\end{array}$ & & 0.791 & 0.359 \\
\hline
\end{tabular}

Sumber : Data diolah, 2019

Berdasarkan Tabel 4.1 diatas terlihat bahwa residual kedua model structural pembentuk path lebih besar dari taraf nyata 0,05\% sehingga disimpulkan bahwa asumsi normalitas terpenuhi.Terlihat pada tabel 4.11 diatas bahwa pengujian asumsi normalitas pengaruh Citra Merek, Kualitas Produk dan Kelompok Acuan Terhadap Keputusan Pembelian menghasilkan statistic uji Kolmpgorov Smirnov Z sebesar 0.651 dengan Asymp Sig. sebesar 0.791, kemudian pengaruh Citra Merek, Kualitas Produk, Kelompok Acuan dan Promosi Terhadap Keputusan Pembelian menghasilkan Statistik Uji Kolmogorov-Smirnov Z sebesar 0.925 dengan probabilitas sebesar 0.359. hasil ini menunjukan bahwa probabilitas > level of significant (5\%). Hal ini berarti residual yang dihasilkan oleh kedua model dinyatakan berdistribusi normal. 


\section{Hasil Uji Asumsi Klasik Uji Heteroskedastisitas}

Tabel 4.2

Hasil Pengujian Asumsi Heteroskedastisitas

\begin{tabular}{|l|l|l|l|l|}
\hline Residu & $\begin{array}{l}\text { Test of } \\
\text { Heteroskedastisitas }\end{array}$ & Sig. & Cut Off & Keterangan \\
\hline \multirow{3}{*}{$\begin{array}{l}\text { Promosi } \\
(\text { Z) }\end{array}$} & Citra Merek & 0.594 & $>0.05$ & $\begin{array}{l}\text { Tidak } \\
\text { Heteroskedastisitas }\end{array}$ \\
\cline { 2 - 5 } & Kualitas Produk & 0.302 & $>0.05$ & $\begin{array}{l}\text { Tidak } \\
\text { Heteroskedastisitas }\end{array}$ \\
\cline { 2 - 5 } & Kelompok Acuan & 0.303 & $>0.05$ & $\begin{array}{l}\text { Tidak } \\
\text { Heteroskedastisitas }\end{array}$ \\
\hline
\end{tabular}

\begin{tabular}{|l|l|l|l|l|}
\hline Residu & $\begin{array}{l}\text { Test of } \\
\text { Heteroskedastisitas }\end{array}$ & Sig. & Cut Off & Keterangan \\
\hline \multirow{2}{*}{$\begin{array}{l}\text { Keputusan } \\
\begin{array}{l}\text { Pembelian } \\
(Y)\end{array}\end{array}$} & Citra Merek & 0.645 & $>0.05$ & $\begin{array}{l}\text { Tidak } \\
\text { Heteroskedastisitas }\end{array}$ \\
\cline { 2 - 5 } & Kualitas Produk & 0.063 & $>0.05$ & $\begin{array}{l}\text { Tidak } \\
\text { Heteroskedastisitas }\end{array}$ \\
\cline { 2 - 5 } & Kelompok Acuan & 0.218 & $>0.05$ & $\begin{array}{l}\text { Tidak } \\
\text { Heteroskedastisitas }\end{array}$ \\
\cline { 2 - 5 } & Promosi & 0.056 & $>0.05$ & $\begin{array}{l}\text { Tidak } \\
\text { Heteroskedastisitas }\end{array}$ \\
\hline
\end{tabular}

Sumber : Data diolah, 2019.

Dari hasil output diatas pada table 4.2, maka tampak bahwa semua variabel tidak ada gejala heteroskedastisitas karena sig. $>0.05$..

\section{Analisis Data}

\section{Analisis Jalur (Path Analysis)}

Tabel 4.4

Hasil Analisis Jalur

\begin{tabular}{|l|l|l|l|l|}
\hline \multicolumn{2}{|l|}{ Standerdized } & \multicolumn{1}{l}{ thitung $t_{\text {tabel }}$} & Sig $\alpha$ & Keterangan \\
\cline { 1 - 4 } Jalur & Beta $(\beta)$ & & & \\
\hline $\mathrm{X} 1-\mathrm{Z}$ & 0.299 & $3.893>1.985$ & $0.000<0.05$ & Signifikan \\
\hline $\mathrm{X} 2-\mathrm{Z}$ & 0.528 & $5.814>1.985$ & $0.000<0.05$ & Signifikan \\
\hline $\mathrm{X} 3-\mathrm{Z}$ & 0.133 & $1.825>1.985$ & $0.071<0.05$ & Tidak Signifikan \\
\hline $\mathrm{X} 1-\mathrm{Y}$ & 0.453 & $8.463>1.985$ & $0.000<0.05$ & Signifikan \\
\hline $\mathrm{X} 2-\mathrm{Y}$ & 0.631 & $9.197>1.985$ & $0.000<0.05$ & Signifikan \\
\hline $\mathrm{X} 3-\mathrm{Y}$ & 0.027 & $0.571>1.985$ & $0.569<0.05$ & Tidak Signifikan \\
\hline $\mathrm{Z}-\mathrm{Y}$ & -0.099 & $-1.45>1.985$ & $0.149<0.05$ & Tidak Signifikan \\
\hline$€ 1$ & 48.166 & - & - & - \\
\hline$€ 2$ & 30.983 & - & - & - \\
\hline
\end{tabular}

Sumber : Data Sudah diolah,2019.

Berdasarkan Tabel 4.4 diatas, maka dapat dibentuk persamaan model empiric berdasarkan hasil koefisien jalur sebagai berikut :

Persamaan Model I :

$Z=0.299 X 1+0.528 \times 2+0.133 \times 3+48.166 \varepsilon 1$ 
Promosi $=0.299$ Citra Merek +0.528 Kualitas Produk +0.133 Kelompok Acuan + 48.166 Variabel Lain

Persamaan Model II :

$Y=0.453 X 1+0.631 X 2+0.027 X 3-0.099 Z+30.983 \varepsilon 2$

$\mathrm{Y}=0.453$ Citra Merek + 0.631 Kualitas Produk + 0.027 Kelompok Acuan 0.099 Promosi + 30.983 Variabel lain.

Pengujian Hipotesis Penelitian

a. Pengujian Signifikan Parsial (Uji t)

Tabel 4.6

Hasil Uji Signifikansi Parsial (Uji t)

\begin{tabular}{|l|c|c|c|c|c|}
\hline Eksogen & Endogen & Koefisiensi & t statistic & Sig. & Keterangan \\
\hline Citra Merek & Promosi & 0.299 & 3.893 & 0.000 & Pengaruh \\
\hline $\begin{array}{l}\text { Kualitas } \\
\text { Produk }\end{array}$ & Promosi & 0.528 & 5.814 & 0.001 & Pengaruh \\
\hline $\begin{array}{l}\text { Kelompok } \\
\text { Acuan }\end{array}$ & Promosi & 0.133 & 1.825 & 0.071 & $\begin{array}{c}\text { Tidak } \\
\text { Berpengaruh }\end{array}$ \\
\hline Citra Merek & $\begin{array}{l}\text { Keputusan } \\
\text { Pembelian }\end{array}$ & 0.453 & 8.463 & 0.000 & Pengaruh \\
\hline $\begin{array}{l}\text { Kualitas } \\
\text { Produk }\end{array}$ & $\begin{array}{l}\text { Keputusan } \\
\text { Pembelian }\end{array}$ & 0.631 & 9.197 & 0.000 & Pengaruh \\
\hline $\begin{array}{l}\text { Kelompok } \\
\text { Acuan }\end{array}$ & $\begin{array}{l}\text { Keputusan } \\
\text { Pembelian }\end{array}$ & 0.027 & 0.571 & 0.569 & $\begin{array}{c}\text { Tidak } \\
\text { Berpengaruh }\end{array}$ \\
\hline Promosi & $\begin{array}{l}\text { Keputusan } \\
\text { Pembelian }\end{array}$ & -0.099 & -1.456 & 0.149 & $\begin{array}{c}\text { Tidak } \\
\text { Berpengaruh }\end{array}$ \\
\hline
\end{tabular}

Sumber : Data diolah, 2019.

\section{c. Hasil Hipotesis :}

Berdasarkan hasil analisis jalur diatas maka diperoleh hasil hipotesis penelitian yang dapat dinyatakan sebagai berikut:

1. Pengaruh Citra Merek Terhadap Promosi

Pengaruh variabel citra merek terhadap promosi diperoleh nilai thitung $>$ $t_{\text {tabel }}(3.893>1.985)$ dan singinifikansi $0.000<0.05$. maka Ho ditolak dan Ha diterima, yang berarti ada pengaruh secara signifikansi citra merek terhadap variabel promosi pada Store Meteor Cell Malang.

2. Pengaruh Kualitas Produk Terhadap Keputusan Pembelian

Pengaruh variabel Kualitas Produk terhadap promosi diperoleh nilai $t_{\text {hitung }}>t_{\text {tabel }}(5.814>1.985)$ dan singinifikansi $0.001<0.05$. maka Ho ditolak dan Ha diterima, yang berarti ada pengaruh secara signifikansi Variabel Kualitas Produk terhadap variabel promosi pada Store Meteor Cell Malang.

3. Pengaruh Kelompok Acuan Terhadap Variabel Promosi

Pengaruh variabel kelompok acuan terhadap promosi diperoleh nilai $t_{\text {hitung }}>t_{\text {tabel }}(1.825>1.985)$ dan singinifikansi $0.071>0.05$. maka Ha ditolak dan Ho diterima, yang berarti tidak ada pengaruh secara signifikansi Variabel kelompok acuan terhadap variabel promosi pada Store Meteor Cell Malang.

4. Pengaruh Promosi Memediasi Pengaruh Citra Merek Terhadap Keputusan Pembelian

Pengaruh variabel Citra Merek terhadap Keputusan Pembelian diperoleh nilai $t_{\text {hitung }}>t_{\text {tabel }}(8.463>1.985)$ dan singinifikansi $0.000<$ 
0.05. maka Ho ditolak dan Ha diterima, yang berarti ada pengaruh secara signifikansi Variabel Citra Merek terhadap variabel Keputusan Pembelian pada Store Meteor Cell Malang.

5. Pengaruh Promosi Memediasi Pengaruh Kualitas Produk Terhadap Keputusan Pembelian.

Pengaruh variabel Kualitas Produk terhadap Keputusan Pembelian diperoleh nilai thitung $>t_{\text {tabel }}(9.197>1.985)$ dan singinifikansi $0.000<$ 0.05. maka Ho ditolak dan Ha diterima, yang berarti ada pengaruh secara signifikansi Variabel Kualitas Produk terhadap variabel Keputusan Pembelian pada Store Meteor Cell Malang.

6. Pengaruh Promosi Memediasi Pengaruh Kelompok Acuan Terhadap Keputusan Pembelian

Pengaruh variabel Kelompok Acuan terhadap Keputusan Pembelian diperoleh nilai $t_{\text {hitung }}>t_{\text {tabel }}(0.571>1.985)$ dan singinifikansi $0.569>$ 0.05. maka Ha ditolak dan Ho diterima, yang berarti tidak ada pengaruh secara signifikansi Variabel Kelompok Acuan terhadap variabel Keputusan Pembelian pada Store Meteor Cell Malang.

7. Pengaruh Variabel Promosi ke Variabel Keputusan Pembelian

Pengaruh variabel Promosi terhadap Keputusan Pembelian diperoleh nilai $t_{\text {hitung }}>t_{\text {tabel }}(-1.456>1.985)$ dan singinifikansi $0.149>0.05$. maka Ha ditolak dan Ho diterima, yang berarti tidak ada pengaruh secara signifikansi Variabel Citra Merek terhadap variabel Keputusan Pembelian pada Store Meteor Cell Malang.

\section{PEMBAHASAN}

\section{Pengaruh citra merek terhadap promosi}

Hasil penelitian ini menunjukan bahwa citra merek berpengaruh positif dan signifikan terhadap variabel promosi. Hasil ini menunjukan bahwa pelanggan Store Meteor Cell Malang lebih memilih type $\mathrm{Hp}$ Samsung dibandingkan dengan merek lain serta harga yang sangat relative murah, merek yang mudah diingat, merek yang mudah diucapkan.

Ada beberapa hal yang dilakukan oleh owner "Store Meteor Cell Malang" dalam rangka melakukan promosi type $\mathrm{Hp}$ samsung kepada masyarakat agar citra merek HP Samsung mudah diingat oleh konsumen dengan memberikan promo-promo akhir bulan bahkan cash back sampai $30 \%$ sehingga menghasilkan penjualan yang sangat bagus sekali.

\section{Pengaruh kualitas produk terhadap variabel promosi}

Hasil penelitian ini menunjukan bahwa kualitas produk berpengaruh positif dan signifikan terhadap promosi, hal ini menunjukan Semakin baik kualitas produk maka cenderung akan mempermudah melakukan promosi kepada konsumen tanpa harus repot-repot lagi Store Meteor Cell Malang menjelaskan tentang kualitas produk Hp Samsung kepada pelanggan.

Ada banyak hal yang dilakukan oleh "Store Meteor Cell Malang" dalam rangka meyakinkan konsumen agar tidak ragu terhadap kualitas 
produk dari Hp Samsung. Diantaranya adalah dengan memberikan garansi resmi, dimana konsumen bener-bener diberikan garansi 1 tahun jika $\mathrm{Hp}$ Samsung mengalami kerusakan sebelum jatuh tempo garansi berakhir $\mathrm{Hp}$ yang mengalami kerusakan akan digantikan dengan Smartphone yang baru lagi demi menjaga kualitas produk.

\section{Pengaruh kelompok acuan terhadap variabel promosi}

Hasil penelitian ini menunjukan bahwa kelompok acuan tidak berpengaruh terhadap promosi. Semakin rendahnya variabel kelompok acuan akan berdampak pada promosi yang dilakukan oleh Store Meteor Cell Malang. Hasil ini menunjukan bahwa pelanggan Store Meteor Cell Malang lebih memilih mencari informasi tentang Smarphone lewat internet bahkan langsung ke Meteor Cell secara langsung ketimbang kelompok acuan ataupun referensi dari kerabat ataupun keluarga, tidak berpengaruhnya kelompok acuan terhadap promosi di dukung oleh profil lulusan dari responden kebanyakan sarjana sebanyak 43 dari total responden 95. Dan pekerjaan responden sebagai karyawan sebanyak 27 responden.

\section{Pengaruh Promosi Memediasi Pengaruh citra merek terhadap keputusan pembelian}

Hasil penelitian ini menunjukan bahwa citra merek berpengaruh positif dan signifikan terhadap keputusan pembelian. Semakin baik citra merek maka cenderung dapat meningkatkan keputusan pembelian. Hasil ini menunjukan bahwa pembeli $\mathrm{Hp}$ Samsung di Store Meteor Cell mendapatkan kepuasaan terhadap citra merek Hp Samsung. hal ini menunjukan bahwa apabila citra merek Hp Samsung di Store Meteor Cell Malang mampu meningkatkan penjualan otomatis akan derdampak pada keputusan pembelian yang berulang kali.

Hasil penelitian ini didukung oleh penelitian yang dilakukan oleh penelitian terdahulu diantaranya : Hermawan (2018).

\section{Pengaruh Promosi Memediasi Pengaruh Kualitas produk terhadap keputusan pembelian}

Hasil penelitian ini menunjukan bahwa kualitas produk berpengaruh positif dan signifikan terhadap keputusan pembelian. Semakin baik kualitas produk maka cenderung dapat meningkatkan keputusan pembelian. Hasil ini menunjukan bahwa pembeli $\mathrm{Hp}$ Samsung di Store Meteor Cell mendapatkan kepuasaan terhadap kualitas produk merek Hp Samsung. Hasil penelitian ini didukung oleh penelitian yang dilakukan oleh beberapa penelitian sebelumnya di anataranya : Maksum (2018).

\section{Pengaruh Promosi Memediasi Pengaruh Kelompok acuan terhadap keputusan pembelian}

Hasil penelitian ini menunjukan bahwa kelompok acuan tidak berpengaruh positif dan signifikan terhadap keputusan pembelian. Semakin menurunya kelompok acuan akan berdampak pada keputusan pembelian. Hasil ini menunjukan bahwa pembeli Hp Samsung di Store Meteor Cell kurang mendapatkan acuan dari kerabat atau bahkan teman terdekat terkait Hp Samsung yang ada di Store Meteor Cell Malang. Hasil penelitian ini bertolak belakang dengan penelitian yang dilakukan oleh penelitian terdahulu diantaranya :Alifia (2017). Iriani (2014). 


\section{Pengaruh Promosi terhadap keputusan pembelian}

Hasil penelitian ini menunjukan bahwa promosi tidak berpengaruh positif dan signifikan terhadap keputusan pembelian. Semakin rendahnya niali promosi maka cenderung dapat menurunya keputusan pembelian. Hasil ini menunjukan bahwa pembeli Hp Samsung di Store Meteor Cell kurang mendapatkan promosi secara langsung terkait $\mathrm{Hp}$ samsung, meskipun Store Meteor Cell Malang memberikan diskon ataupun cash back $30 \%$ - 50\% tidak mempengaruhi consumen untuk melakukan pembelian. Hasil penelitrian ini bertolak belakang dengan penelitian yang dilakukan oleh penelitian terdahulu di antaranya : Bawono (2018).

\section{SIMPULAN DAN SARAN}

Penelitian ini bertujuan untuk mengetahui pengaruh langsung dan tidak langsungnya variabel citra merek, kualitas produk, kelompok acuan dan promosi terhadap keputusan pembelian smartphone Hp Samsung di Store Meteor Cell Malang.

Berdasarkan hasil analisis jalur diatas maka diperoleh hasil hipotesis penelitian yang dapat dinyatakan sebagai berikut :

1) Pengaruh Citra Merek Terhadap Promosi

Pengaruh variabel citra merek terhadap promosi dengan hasil penelitianya ada pengaruh secara signifikansi citra merek terhadap variabel promosi pada Store Meteor Cell Malang. Dengan demikian hipotesis 1 terpenuhi.

2) Pengaruh Kualitas Produk Terhadap Keputusan Pembelian

Pengaruh variabel Kualitas Produk terhadap promosi dengan hasil penelitianya ada pengaruh secara signifikansi Variabel Kualitas Produk terhadap variabel promosi pada store Meteor Cell Malang. Dengan demikian hipotesis 2 terpenuhi.

3) Pengaruh Kelompok Acuan Terhadap Variabel Promosi

Pengaruh variabel kelompok acuan terhadap promosi dengan hasil penelitiannya bahwa tidak ada pengaruh secara signifikansi Variabel kelompok acuan terhadap variabel promosi pada Store Meteor Cell Malang. Dengan demikian hipotesis 3 tidak terpenuhi.

4) Pengaruh Promosi Memediasi Pengaruh Citra Merek Terhadap Keputusan Pembelian

Pengaruh variabel Citra Merek terhadap Keputusan Pembelian dengan hasil penelitiannya ada pengaruh secara signifikansi Variabel Citra Merek terhadap variabel Keputusan Pembelian pada Store Meteor Cell Malang. Dengan demikian hipotesis 4 terpenuhi.

5) Pengaruh Promosi Memediasi Pengaruh Kualitas Produk Terhadap Keputusan Pembelian

Pengaruh variabel Kualitas Produk terhadap Keputusan Pembelian dengan hasil penelitiannya ada pengaruh secara signifikansi Variabel Kualitas Produk terhadap variabel Keputusan Pembelian pada Store Meteor Cell Malang. Dengan demikian hipotesis 5 terpenuhi.

6) Pengaruh Promosi Memediasi Pengaruh Kelompok Acuan Terhadap Keputusan Pembelian 
Pengaruh variabel Kelompok Acuan terhadap Keputusan Pembelian dengan hasil penelitiannya tidak ada pengaruh secara signifikansi Variabel Kelompok Acuan terhadap variabel Keputusan Pembelian pada Store Meteor Cell Malang. Dengan demikian hipotesis 6 tidak terpenuhi.

7) Pengaruh Variabel Promosi ke Variabel Keputusan Pembelian

Pengaruh variabel Promosi terhadap Keputusan Pembelian dengan hasil penelitiannya tidak ada pengaruh secara signifikansi Variabel Citra Merek terhadap variabel Keputusan Pembelian pada Store Meteor Cell Malang. Dengan demikian hipotesis 7 tidak terpenuhi.

\section{Pengaruh Langsung Maupun Tidak Langsung}

1) Koefisien pengaruh langsung citra merek terhadap promosi, hal ini menunjukan bahwa citra merek berpengaruh positif dan signifikan terhadap promosi. Dengan demikian semakin baik citra merek maka akan dapat mempermudah perusahaan dalam melakukan promosi.

2) Koefisien pengaruh langsung Kualitas produk terhadap promosi , hal ini menunjukan bahwa kualitas produk berpengaruh positif dan signifikan terhadap promosi. Dengan demikian semakin baik kualitas produk maka akan dapat mempermudah perusahaan dalam melakukan promosi.

3) Koefisien pengaruh langsung Kelompok acuan terhadap promosi, hal ini menunjukan bahwa kelompok acuan tidak berpengaruh positif dan signifikan terhadap promosi.

4) Pengaruh langsung citra merek terhadap keputusan pembelian, hal ini menunjukan bahwa variabel citra merek berpengaruh positif dan signifikan terhadap keputusan pembelian. Dengan demikian semakin baik citra merek maka akan semakin cenderung dapat meningkatkan keputusan pembelian.

5) Pengaruh langsung Kualitas produk terhadap keputusan pembelian , hal ini menunjukan bahwa variabel Kualitas produk berpengaruh positif dan signifikan terhadap keputusan pembelian. Dengan demikian semakin baik kualitas produk maka akan semakin cenderung dapat meningkatkan keputusan pembelian.

6) Pengaruh langsung Kelompok Acuan terhadap keputusan pembelian, hal ini menunjukan bahwa variabel Kelompok acuan tidak berpengaruh positif dan signifikan terhadap keputusan pembelian. Dengan demikian semakin rendah niali kelompok acuan maka akan semakin menurunnya minat konsumen terhadap keputusan pembelian.

7) Pengaruh langsung promosi terhadap keputusan pembelian, hal ini menunjukan bahwa variabel promosi tidak berpengaruh positif dan signifikan terhadap keputusan pembelian. Dengan demikian semakin rendah nilai koefisien direct promosi maka akan semakin menurunnya minat konsumen terhadap keputusan pembelian.

8) Koefisien pengaruh tidak langsung citra merek terhadap keputusan pembelian melalui promosi, hal ini menunjukan bahwa citra merek tidak berpengaruh positif dan signifikansi terhadap keputusan pembelian melalui promosi. Dapat diartikan disini bahwa semakin 
tidak baiknya citra merek dimata konsumen maka akan cenderung dapat menggurangi minat keputusan pembelian konsumen.

9) Koefisien pengaruh tidak langsung kualitas produk terhadap keputusan pembelian melalui promosi, hal ini menunjukan bahwa kualitas produk tidak berpengaruh positif dan signifikansi terhadap keputusan pembelian melalui promosi. Dapat diartikan disini bahwa semakin tidak baiknya kualitas produk dimata konsumen maka akan cenderung dapat menggurangi minat keputusan pembelian konsumen.

10) Koefisien pengaruh tidak langsung kelompok acuan terhadap keputusan pembelian melalui promosi, hal ini menunjukan bahwa kelompok acuan tidak berpengaruh positif dan signifikansi terhadap keputusan pembelian melalui promosi.

Berdasarkan hasil penelitian yang telah dikemukakan diatas, maka saran yang dapat direkomendasikan untuk menjdai pertimbangan bagi penelitian selanjutnya adalah sebagai berikut :

1. Melakukan penelitian diluar variabel bebas yang mempengaruhi keputusan pembelian yang digunakan dalam penelitian ini yaitu citra merek, kualitas produk, kelompok acuan dan promosi karena terdapat variabel lain brand switching, harga dan motivasi ataupun lokasi.

2. Bagi penelitian selanjutnya, disarankan untuk bisa mengidentifikasi dan mendeskripsikan lebih luas tentang responden yang digunakan dalam penelitian ini, karena smarphone Samsung tidak hanya digunakan oleh kalangan remaja saja akan tetapi dari kalangan orang tua juga ada., mulai dari ibu rumah tangga hingga orang yang berkerja dikantor.

3. Bagi penelitian selanjutnya disarankan untuk lebih komunikatif dengan respoden dan memilih waktu yang sangat tepat pada saat akan menyebarkan kuesioner. Sebaiknya peneliti tidak menyebarkan angket atau kuesioner pada waktu dimana responden sedang sibuk ataupun lelah karena dapat berpengaruh pada jawaban angket atau kuesioner yang diisiresponden.

\section{DAFTAR PUSTAKA}

Alifia, Rahayu. 2017. Dalam jurnalnya "Pengaruh Persepsi Harga, Kelopok Acuan dan Coutry of origin Terhadap Keputusan Pembelian". Diakses pada tanggal 20 agustus. 2018. pukul.18.00.

Bawono, Adhi. 2018. Dalam jurnal "Pengaruh Perilaku Konsumen, Brand Image dan Promosi Terhadap Keputusan Pembelian Online Pada Situs Belanja Online". Jurnal Pengabdian dan Kewirausahaan Vol.2 No.2 131-144, 2018 p-ISSN:2581-2718 e-ISSN:2620-3480. Sekolah Tinggi Ilmu Komunikasi dan Sekretari Tarakanita.

Djaslim, Saladin. 2004. Manajemen Pemasaran, Analisis, Perencanaan, Pelaksanaan dan Pengendalian. Penerbit : Linda Karya.

Dharmmesta, B. S. dan Handoko, T. H. 2008. Manajemen Pemasaran.Analisis Perilaku Konsumen. Jogyakarta : BPFE. 
Ghozali, Imam. 2016. Aplikasi Analisis Multivariate Dengan Program IBM SPSS 23 (Edisi). Cetakan ke VII. Semarang. Badan Penerbit. Universitas Diponegoro.

Hermawan, Erin. G. 2018. Dalam jurnal "Analisis Pengaruh Citra Merek, Kualitas Produk, dan Harga Terhadap Keputusan Pembelian Kartu Prabayar Telkomsel Simpati (Studi Pada Mahasiswa Fakultas Ekonomi dan Bisnis Universitas Muhamadiyah Surakarta". Program studi manajemen.Fakultas Ekonomi Universitas Muhamadiyah Surakarta

Indriantoro, Nur dan Bambang, Supomo. 2002. Metodelogi Penelitian Bisnis. Yogyakarta:BPPE.

Iriani. S dan Anoraga. J . 2014. Dalam jurnalnya "Pengaruh Gaya Hidup dan Kelompok Acuan Terhadap Keputusan Pembelian Smartphone Merek Samsung Galaxy". Jurusan manajemen Fakultas Ekonomi Universitas Negeri Surabaya.Jurnal BISMA.jurnal Bisnis dan Manajemen Volume 6 No.2 Febuari 2014. Diakses pada tanggal 2 Desember 2018.

Kotler, Philip dan Amstrog, Gary. 2013. Prinsip-Prinsip Pemasaran, Edisi ke 12 Penerbit : Erlanga. 2012. Prinsip-prinsip Pemasaran. Edisi 13 Jilid 1. Jakarta : Erlangga.

2012. Principles of Marketing. Edisi 14 New Jersey: Prentice-Hall Published.

... 2008. Prinsip-prinsip Pemasaran Edisi 12 Jilid 1 Jakarta : Erlangga.

Maksum, Rifa"l. 2018. Dalam jurnal "Pengaruh Brand Abbassador dan Kualitas Produk Terhadap Keputusan Pembelian Dengan Brand Image Sebagai Variabel Intervening". E-jurnal riset manajemen fakultas ekonomi unisma.

Peter, J. Paul dan Olson, Jerry. C. 2014. Perilaku Konsumen dan Strategi Pemasaran. Edisi Kesembilan Buku 2. Jakarta : Erlangga.

Santoso, Singgih. 2012. Statistik Parametrik.Jakarta : PT.Gramedia Pustaka Umum.

Schiffman, Leon. G dan Kanuk, Leslie. L. 2008. Perilaku Konsumen Edisi Ke Tujuh Jakarta : PT.Indeks.

Tjiptono, Fandy. 2008. Strategi Pemasaran. Yogyakarta : Andi Offset. 